\title{
THE IMPORTANCE AND NECESSITY OF ENTREPRENEURIAL EDUCATION FOR STUDENTS WITHIN THE TEXTILE AND POLYGRAPHY FACULTY: RESEARCH STUDY
}

\author{
Maria Gheorghita*, ORCID ID: 0000-0002-2177-3497, \\ Angela Ghelbet, ORCID ID: 0000-0001-5709-7016, \\ Valentina Bulgaru, ORCID ID: 0000-0003-3105-4012, \\ Angela Sripcenco, ORCID ID: 0000-0002-9896-6203 \\ Technical University of Moldova, 168 Ștefan cel Mare Blvd., MD-2004, Chișinău, Republic of Moldova \\ *Corresponding author: Maria Gheorghita, maria.gheorghita@emin.utm.md
}

Received: 01. 20. 2022

Accepted: 02. 24. 2022

\begin{abstract}
Entrepreneurial education is considered as one of the priority directions for the development of the education system both at international level and in the Republic of Moldova. Research has shown that investing in entrepreneurial education is one of the most profitable investments, and young people who have benefited from entrepreneurial education are more likely to start their own business at some point in their lives. Over the last decade, the governments of several states have paid particular attention to the aspects of legislative support for the entrepreneurial training process in the education system. Given the context of global change and the pronounced demographic decline in the Republic of Moldova, lifelong learning is considered an important concern of the education system. Thus, in recent years, various projects have been launched at national level to support the development of entrepreneurial education. The European Union funded and recently launched Collaborative Entrepreneurial Education project that aims to increase access to quality entrepreneurship training, development students' entrepreneurial skills, and train a new generation of entrepreneurs for the textile industry, which is a key industry in Moldova. Through this project, the importance and necessity of entrepreneurial education for students were identified based on a survey conducted at the Faculty of Textiles and Polygraphy in the Technical University of Moldova, and the results were compared with the results of the survey from the Faculty of Industrial Design and Business Management within the "Gheorghe Asachi" Technical University of Iași, Romania.
\end{abstract}

Keywords: entrepreneurial education, education system, lifelong learning, textile industry, research study.

Rezumat. Educaţia antreprenorială este considerată ca fiind una din direcțiile prioritare de dezvoltare a sistemului educațional atât la nivel internațional, cât și în Republica Moldova. Cercetările au demonstrat că investiția în educația antreprenorială este una dintre cele mai rentabile investiții, iar tinerii care au beneficiat de educație antreprenorială au șanse mai mari de a deschide o afacere proprie, într-un anumit moment al vieții. Pe parcursul ultimului deceniu guvernele mai multor state au atras o atenție deosebită aspectelor de susținere legislativă a procesului de formare antreprenorială în cadrul sistemului de învățământ. 
Reieșind din contextul schimbărilor globale și al declinului demografic pronunțat în Republica Moldova, învățarea pe tot parcursul vieții este considerată drept o preocupare importantă a sistemului educațional. Astfel, în ultimii ani la nivel național au fost lansate diferite proiecte de susținere a dezvoltării educației antreprenoriale. Proiectul "Collaborative Entrepreneurial Education”, finanțat de Uniunea Europeană și lansat recent are drept obiectiv principal sporirea accesului la o instruire calitativă în domeniul Antreprenoriatului, dezvoltarea abilităților antreprenoriale ale studenților, formarea unei generații noi de antreprenori pentru industria textilă care este o industrie cheie a economiei Moldovei.

Prin intermediul acestui proiect au fost identificate importanța si necesitatea educației antreprenoriale a studenților in baza unui sondaj efectuat la Facultatea "Textile și Poligrafie" din cadrul Universității Tehnice a Moldovei, iar rezultatele au fost comparate cu rezultatele sondajului efectuat la Facultatea de "Design Industrial și Managementul Afacerilor" din cadrul Universității Tehnice “Gheorghe Asachi” din Iași, România.

Cuvinte cheie: educație antreprenorială, sistem educațional, învățare pe parcursul vieții, industria textilă, studiu de cercetare.

\section{Introduction}

In the last decade, both in the European Union and the Republic of Moldova, especially young people are facing the problem of identifying a suitable job, thus achieving a perfect adjustment in the economic gear. Analyzes and statistical reports show that the unemployment rate among young people under age of 25 in the European Union is 22\% [1] and in the Republic of Moldova the unemployment rate among young people (15-29 years) is even higher and ranges between $28,4 \%$ and about $31-33.3 \%$. This value of the indicator differs depending on the variable "number of young people missing from the country for more than 12 months due to migration" [2].

These data have highlighted the need to adopt sustainable solutions for the prosperity of future generations. Thus, in 2006, the European Parliament set some recommendations on certain curricular disciplines that are considered key competences in the learning process, such as civic education and foreign languages, entrepreneurship education.

It should be mentioned that Entrepreneurship, as a study discipline has to contribute to the mentality changes, so that the person understands and accepts business principles and models. Therefore, entrepreneurship education needs to be developed from an early age, not even in school-age children, but earlier at primary school or at least in secondary school. Both high school children and especially students, need certain business skills to understand what a business is, from what sources it can be funded, how the costs and profits are formed, what reflects the break-even point and knowledge of the risks, etc. Emphasis should be focused not only on knowledge transfer, but also on the acquisition of general entrepreneurial skills, the development of the abilities to identify opportunities, make decisions and take responsibility for own decision, the stimulus of self-organization, including the formation of specific social skills. And success in this area depends on the optimal way to ensure efficient entrepreneurship education.

\section{The international and national context of entrepreneurial education}

The international context

Entrepreneurship support and development is very important, because the implications of globalization are most obvious in the economy and including business and to 
integrate into such a society, young people must cultivate specific skills and abilities that can help them to adapt to continuous change.

Research has shown that investing in education is undisputed, and entrepreneurial education is considered one of the most profitable investments, so young people who have benefited from entrepreneurial education are from 3 to 6 times more likely to start their own business and managed successfully at a certain stage of thier life, compared to those who did not have the opportunity to benefit from entrepreneurial education. Entrepreneurial education provides students with additional knowledge and skills, which are much needed to be applied on the starting a new business [3]. It also develops and stimulates the entrepreneurial process, providing the tools needed to launch new businesses [4].

According to some researchers, entrepreneurial education is a deliberate intervention of teachers/trainers in students' lives to train them entrepreneurship, develop their knowledge and skills needed to work in business [5].

Grateful to that entrepreneurship plays a decisive role in economic development [6], the governments of different countries have started to encourage people to become entrepreneurs [7]. Particular attention has been paid to this process by the European Union. Over the last two decades, the European Union has attracted, and continues to attract a special focus on entrepreneurial education. The European Commission for the first time was mentioned the importance of entrepreneurial education in 2003 in the European Commission's Green Paper on Entrepreneurship.

In 2006, the European Parliament and the Council of the European Union adopted the Recommendation on Key Competences for Lifelong Learning. This Recommendation addresses the development of key competences for all members of society as a content of lifelong learning strategies, including strategies for achieving universal literacy, by applying the concept of "Key competences for lifelong learning - A European Framework" [8].

The spirit of initiative and entrepreneurship is one of the eight key competencies needed for all members of a knowledge-based society. The recommendation was a key reference document for policy-making in education, for the development of skills-oriented training and learning, including entrepreneurial competence. The European Commission recognizes entrepreneurial education as a proven tool that helps young people become more entrepreneurial. In addition to specific skills, entrepreneurship training contributes to the development of a general set of skills, applicable in all aspects of life. It encompasses the various forms of learning, education and training that through their synergy contribute to the creation of the spirit, skills and entrepreneurial behavior, with or without a business objective.

The European Union has always mentioned the need to promote entrepreneurial education. The Small Business Act for Europe was approved in 2008, the Communication about Rethinking Education was launched in 2012, and the Entrepreneurship 2020 - Action Plan was approved in 2013. Through the Entrepreneurship 2020 Action Plan, the European Commission emphasized that business and entrepreneurial skills and abilities are key competences in lifelong learning, important factors that would favorably influence the low growth rate and significantly reduce the large number of unemployed through firm measures in the short and medium term to promote Entrepreneurship and creating conducive conditions to its development, especially among young people [9].

And more recently, the "New Skills Agenda for Europe: Working together to strengthen human capital, employability and competitiveness" to address the skills challenges facing Europe, the Entrepreneurship Framework, also known as EntreComp, provides a tool for 
improving the entrepreneurial capacity of European citizens and organizations. EntreComp defines "Entrepreneurship as a transversal competence, which applies in all spheres of life: from promoting personal development, to active participation in society, to (re) entering the labor market as an employee or as a self-employed person and also, until the creation of cultural, social or commercial projects. Entrepreneurship is when one acts on the basis of opportunities and ideas, turning them into value for others, and the value that is created can be financial, cultural or social" $[10,11]$.

Entrepreneurial education began in the United States in the 1970s, when the University of Southern California launched its first program MBA in entrepreneurship in 1971, followed by its first bachelor's degree program in 1972. In the early 1980s, more than 300 universities offered entrepreneurship and small business courses and in the 1990s this number increased to 1,050 schools. Therefore, the true emergence of entrepreneurial education took place in the 1980s [12]. Entrepreneurship continues to grow in business and academia. Currently, more than 1,600 colleges and universities in the United States offer entrepreneurship courses. In the United States, the development of entrepreneurial education is carried out extensively and based on various projects aimed at stimulating the initiatives of young people, which favors the context of bringing the business environment closer to the academic and professional environment. Among the largest projects implemented in the US in the field of entrepreneurship support can be mentioned the Global Business Challenge. This project allows students to work together to present a solution of a real-life business problem which is facing a number of companies participated in the project. In order to find the optimal solution to a problem, teams of students from all over the world are formed and compete to come up with the best solution.

\section{The national context}

In the Republic of Moldova, the entrepreneurial environment is a developing process aimed at attracting young people to increase it, and entrepreneurship education has become an important element of initial and continuing training of specialists in various fields, due to the importance of its contribution to the development of entrepreneurship.

In the view of specialists, an entrepreneur can become any person, regardless of the profession or trade he embraces when is doing certain studies. We can say that there are certain professions or trades intended for the training of entrepreneurs. The entrepreneur can belong to any professional group and must be promoted as an alternative to the classic professional career. It is important to create entrepreneurial (transversal) skills for young people. They include a set of knowledge and skills such as initiative, creativity, risk-taking, a sense of responsibility, ability to identify and use opportunities that help young people to turn ideas into action. All these skills need to be developed in young people in vocational training with the help of entrepreneurship education, taking into account the fact that it favors the approach of future specialists to the labor market.

In this sense, the Education Code of the Republic of Moldova (Chapter II, art. 6) reorients the aims of education towards formation a system of competencies that allows active involvement of the individual in social and economic life. The Education Code emphasizes that "The educational ideal of the school in the Republic of Moldova consists in the formation of personalities with a spirit of initiative, capable to self-development, who possess not only a system of knowledge and skills necessary for employment, but also is independent in opinion and action, being open for intercultural dialogue in the context of 
the assumed national and universal values", and one of the key competencies indicated in art. 11 is entrepreneurial competence and initiative [13].

Also in the Strategy "Education-2020" of the Republic of Moldova, the goal was emphasis on changing the focus in education in favor of quality and skills that young people acquire in the educational process. The success of the individual depends on his ability to adapt to changes and lifelong learning, and the education system must provide an adequate environment for development of these skills. In the context of global metamorphoses and the sharp demographic decline, lifelong learning is becoming an important concern of the education system". Specific objective 2.4 of the Strategy also emphasized the need to "modernize the university curriculum from the perspective of focusing on skills, learning and the needs of the economic environment" [14].

The concept of the Education Development Strategy for 2021-2030 “Education-2030", including in the Implementation Program, states that the strategic goal in the field of education is to provide opportunities for all citizens of the Republic of Moldova to develop, from the earliest age and throughout life, skills needed to reach their full potential in personal and family life, as well as professional and social life, and to adapt as easily as possible to the imperatives of the time, in particular to those related to sustainable development ", which means the acquisition of transversal entrepreneurial skills [15]. Thus, in the Republic of Moldova, entrepreneurial education is supported in terms of legislation.

It should be noted that in recent years, various projects have been launched at national level to support the development of entrepreneurial education, promoted by various organizations and centers. Among the most important organizations can be highlighted: Junior Achievment, a public association whose activity is built around the mission of motivating and preparing students so that they can successfully assert themselves in the market economy; The Center for Entrepreneurial Education and Business Assistance (CEDA) supports education reforms, promotes entrepreneurship and income-generating activities as a foundation for quality vocational training and career education, with the aim of training and capitalizing on professional skills, individual initiative and entrepreneurship; Yep Moldova, Artcor, Ziphouse, Tekwill, Mediacor and other centers, whose mission is to promote entrepreneurial education. Students and entrepreneurs who are just starting out or who have businesses and want to introduce innovative products, or young people who are thinking of developing a start-up taking part in such centeras. It is appreciated that the implementation by the mentioned centers of projects for the development of creativity, innovation, innovative culture, innovative business environment contributes significantly to the development of entrepreneurial education and will contribute to the formation and development of a prosperous nation.

Entrepreneurial education is also implemented and promoted by universities in the Republic of Moldova. We mention that several faculties have identified the entrepreneurship course as opportune, and this discipline is found in the bachelor's and master's degree curricula.

\section{Identification of the needs for advanced entrepreneurial education in light industry The importance of light industry for the economy of the Republic of Moldova}

The light industry sector includes textile, clothing, leather, leather goods production, the manufacture of footwear and fashion accessories, it is among the key industries of the Republic of Moldova and contributes annually with approx $5 \%$ on gross domestic product. However, the importance of light industry for the national economy is due to its export. 
Annually light industry is in the top three largest exporters and provides a share of over $14 \%$ of the country's total export. The main is the European market, which has a share of almost $80 \%$. The light industry offered in 2020 jobs to approx. 24.3 thousand people, which constituted over $20 \%$ of the total number of employees in the industry of country [16].

The number of enterprises in this industry has a continuous growth trend (Figure 1).

The data in Figure 1 show that over the five years the number of enterprises registered in the light industry increased by 149 enterprises or by $31.5 \%$ (from 562 enterprises in 2016 to 711 enterprises in 2020). It should be mentioned that in 2020, even despite the Covid-19 pandemic period, new enterprises were created in the branch, which conditioned the increase of the number of enterprises in 2020 by 31 units compared to 2019.

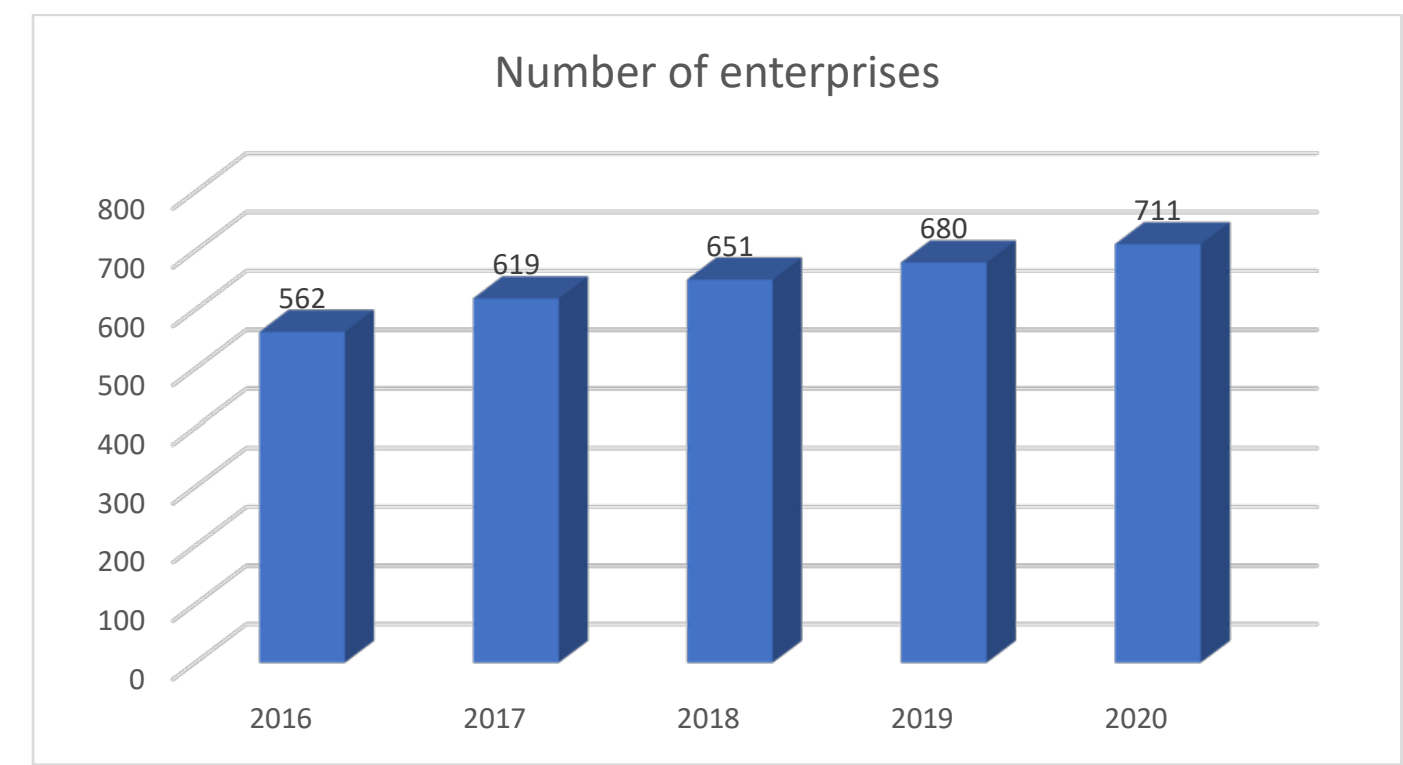

Figure 1. Dynamics of the number of enterprises in the light industry of the

Republic of Moldova

Source: Developed by authors based on [17].

Figure 2 reflect the dynamics of the structure of light industry enterprises, which shows that within five years, the share of large enterprises decreased from $5.5 \%$ in 2016 to $4.6 \%$ in 2020 , and the share of micro, small and medium enterprises increased from $94.5 \%$ to $95.4 \%$.

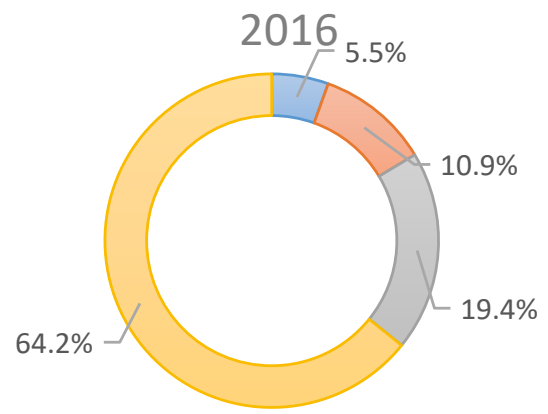

$\square$ Large enterprises

$\square$ Small businesses $\square$ Medium enterprises

$\square$ Micro enterprises

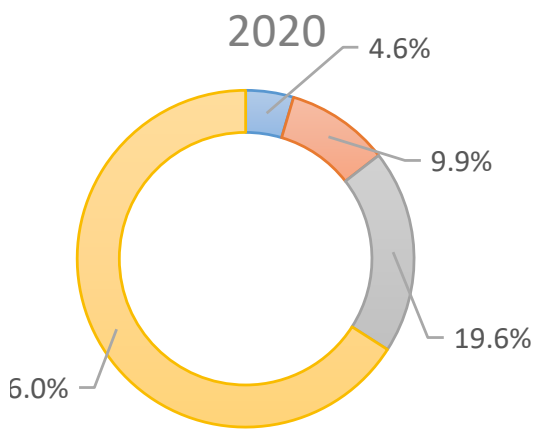

Large enterprises $\square$ Medium enterprises

Small businesses $\square$ Micro enterprises

Figure 2. Dynamics of the structure of enterprises in the light industry of Moldova Source: Developed by authors based on [17]. 
The share of micro-enterprises increased during this period from $64.2 \%$ to $66 \%$. The relatively large number of micro-enterprises, which is constantly growing (from 361 enterprises in 2016 to 449 enterprises in 2020) demonstrates an increased interest in entrepreneurship in this branch. Practice shows that more and more young people are getting involved in entrepreneurship, and every second business is run or owned by a lady.

\section{Collaborative Entrepreneurial Education Project}

The importance and need for the development of light industry in the Republic of Moldova as a priority industry of the national economy is obvious. One of the main challenges in this context is the development of entrepreneurial skills of students at the Technical University of Moldova and training a new generation of entrepreneurs for the light industry.

The positive trends that have emerged in the light industry of the republic need to be sustained, and entrepreneurial education to be widely implemented, in order to motivate more and more young people to open businesses and stay at home for developing our country.

To this end, in 2020 the "Collaborative Entrepreneurial Education" project was launched, financed by the European Union through the Romania-Moldova Cross-Border Program, implemented by the Organization for Development of Small and Medium Enterprises Sector in RM in partnership with Technical University of Moldova, Gheorghe Asachi Technical University lași and County Board of Small and Medium Enterprises, laşi Romania [18].

The main objective of the project is to increase access to quality training in entrepreneurship, develop students' entrepreneurial skills, train a new generation of entrepreneurs for the textile industry based on effective cooperation to identify and use existing best practices at Gheorghe Asachi Technical University (Iasi, Romania) and Technical University of Moldova in the field of entrepreneurial education.

In order to achieve the proposed goal, the following tasks have been formulated and performed:

- to find out the opinion and attitude of the students towards the entrepreneurial activity;

- to identify what opportunities for development, in the opinion of students, exist for entrepreneurship in light industry in Republic of Moldova;

- to understand the main barriers and risks that, in the opinion of students, prevent to start their own business;

- to identify the directions/areas of support needed to facilitate start of one's own business;

- to determine training needs in the field of entrepreneurship;

- to study good practices of European universities regarding the training in the field of entrepreneurship, in order to reapply them in the Technical University of Moldova.

\section{Research methodology}

Entrepreneurial skills in general and for students from the Technical University of Moldova in particular are an underused area, giving priority to specialized engineering education, although the Council of Europe recommendations to the spirit of initiative and entrepreneurship emphasize their importance for integration and professional development. 
Initiating students in accordance with current realities is a framework of maximum interest. In this regard, a study was conducted, based on the opinions and attitudes of students at the Technical University of Moldova, to identify their development needs in the field of entrepreneurship [19]. The study methodology for identifing the students needs and priorities in the field of entrepreneurial skills training aimed to bring conceptual and practical changes in the educational process.

In developing the methodology, the following specific objectives were taken into account:

- identifying the students' opinion on the knowledge and skills in the field of entrepreneurship that they accumulate during their university studies;

- establishing students' expectations regarding the knowledge, skills and attitudes intrinsic to the applied competence;

- identifying the training areas considered by students as necessary for their entrepreneurial development;

- $\quad$ preparing students to participate in lifelong learning.

The study methodology for identifing and assess the needs for training entrepreneurship for students of the Textile and Polygraphy Faculty of the Technical University was based on the method of questioning using the SPIN technique, which is among the most recognized techniques developed in recent years. It was designed to focus on the respondent, so that he/she can realize problems and feel the need to change the situation, in our case, to develop in the entrepreneurial field. This technique makes it possible to identify respondents' needs with a well-structured system of questions, arranged in a certain order [20]. Gratfull to cross-border cooperation between the "Gheorghe Asachi" Technical University of Iași, Romania and Technical University of Moldova, in order to increase students' access to quality entrepreneurship oriented education, the study was based on an identical common questionnaire.

Given that the questionnaire is the basic tool of the investigation, it was used in a quantitative approach to collect the data and information needed for research.

In preparing the questionnaire, the following conditions were taken into account:

- to allow the accumulation of the information necessary for a certain study, to be as short and simple as possible but to provide relevant information;

- to ensure the most complete answers possible;

- to eliminate insignificant information;

- to give answers without too much effort;

- contain filter questions;

- facilitate evaluations, analyzes and interpretations as relevant as possible.

The questionnaire included four blocks of questions, namely:

- situational questions;

- problematic questions;

- impact questions;

- solution questions.

Based on the initial analysis of the primary data and the context, taking into account the specific objectives of the study, the concept and structure of the questionnaire were established, and 18 relevant questions were formulated. The developed questionnaire was used to survey students by both universities in online format, based on Google Forms application. 


\section{Sample and procedures}

At Textile and Polygraphy Faculty of Technical University of Moldova, more than 260 students enrolled in two cycles of study (cycle I - License and cycle II - Master). The survey involved 130 students, or $50 \%$ of the total number of students from faculty.

The surveyed sample included students from all years of study, both from the first and second cycle, as well as from all the specialties of the faculty. The structure of the sample surveyed by years of study was as follows:

- Undergraduate studies, Year 1 - 39 students or $30 \%$,

- Undergraduate studies, Year 2 - 23 students or $18 \%$,

- Undergraduate studies, Year 3 - 32 students or $25 \%$,

- Undergraduate studies, Year 4 - 27 students or $21 \%$,

- Master studies - 9 students or $7 \%$.

The survey was also attended by 100 students from the Faculty of "Industrial Design and Business Management" at the "Gheorghe Asachi" Technical University in Iasi, Romania. Thus, a total number is 230 students participated in the study from both universities.

\section{Results and discussions}

One of the questions in the questionnaire was to understand the attitude of students towards entrepreneurship. It was referring to: What will you do after graduating from university?

Based on the analysis of the answers provided by the students of the Textile and Polygraphy Faculty of the Technical University of Moldova, it is observed that the largest share of respondents $33 \%$ (43 out of 130), focus on launching and developing their own business (Figure 3 ). The answers obtained to this question show that students are thinking about their future and more than a third are interested in entrepreneurship.

\section{Number of respondents}

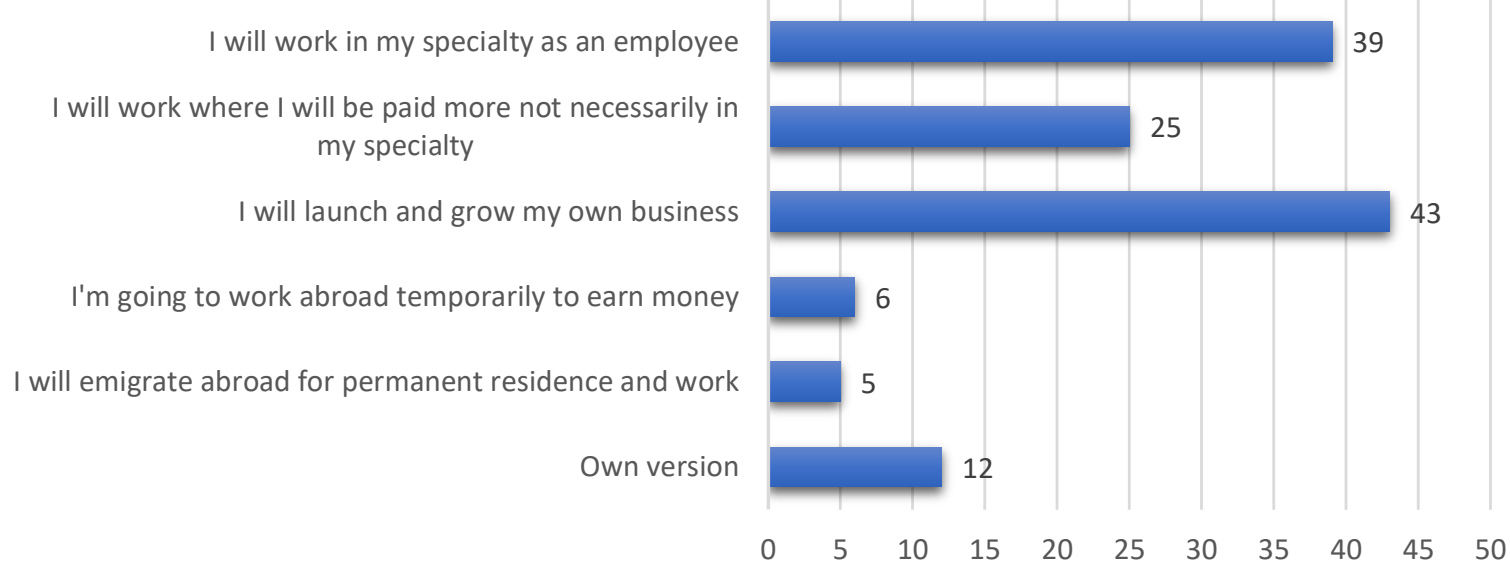

Figure 3. Respondents' answers to the question "What will you do after graduating from university?"

Source: [19].

The study also showed some focus points [19].

- For most students (58\% of students surveyed), the term "entrepreneurship" means the opportunity to realize and put into practice their own ideas. These students are ambitious, full of ideas and aspirations.

- Most students plan to start their own business after graduation. Most of them have business ideas, but they don't know how to implement them. A large proportion, 
approximately $90 \%$ of the students in the target group who took part in the study, have a clear view that their knowledge and skills in entrepreneurship are very useful for their future success, which indicates their interest in gaining new knowledge and skills for employment or starting your own business.

- Students find that there are many obstacles to transforming ideas into their own business, the main one being the lack of knowledge and entrepreneurial skills. $64 \%$ of respondents believe that the knowledge and skills they acquire in the university curriculum is not enough to implement a business idea, and $100 \%$ of respondents are aware of the need to acquire knowledge in the field of entrepreneurship. About 1/4 of the respondents consider that the lack of entrepreneurial experience is an essential obstacle to implementing ideas in their own business. Thus, students' responses reflect the fact that students opt for more indepth entrepreneurial training.

- About $85 \%$ of students consider that such course modules as Basics of Entrepreneurship, Stages of setting up a business, Approaching business in crisis situations, How to attract and retain customers and Risks of entrepreneurship are strictly necessary to be taught in higher education institutions. Over $90 \%$ of respondents expressed an increased interest in being able to identify the sources of financing a business.

- Regarding teaching methods, a large number of students mentioned that it is necessary to apply teaching methods based on concrete examples, dialogue with successful entrepreneurs, practical activity and the use of modern technologies.

Comparing and analyzing the answers of the students from the partner universities, it can be concluded that the students answered very similar questions, expressing similar opinions, wishes and aspirations.

Among the important tasks of the study was to understand how students assess their level of knowledge and entrepreneurial skills that they acquire in the university program. The majority of students in the Republic of Moldova, as well as in Romania, $44 \%$ and $43 \%$, respectively, consider that the knowledge and skills acquired during university studies in entrepreneurship are not enough to ensure their future success. Also, among the answer options, the largest share, $36 \%$ of Moldovan students and $40 \%$ of Romanian students, mentioned that more practice is needed to be able to apply the knowledge gained.

It should be noted that the desire of students to be trained in entrepreneurship is very high. Thus, $82 \%$ of Moldovan students and $73 \%$ of Romanian students want to acquire more knowledge and entrepreneurial skills. Students from both countries have shown a high degree of interest in attending a course, where they can gain basic knowledge and skills in business and entrepreneurship.

\section{Conclusions}

In recent years, both internationally and at European level, there has been a strong emphasis on promoting and implementing entrepreneurial education, especially for young people. However, the implications of globalization are most evident in the economy and including business, and in order to integrate into such a society, young people need to cultivate specific skills and abilities that can enable them to adapt to continuous changes.

Practice has shown that entrepreneurial education is successful when the mentality is ready to accept business principles and models. Therefore, entrepreneurial education should be developed early to school-age children. This conclusion is supported and promoted by a series of legislative acts and programs of the European Union in which recommendations have been adopted on key competences for lifelong learning in Republic of Moldova. 
A successful entrepreneurial education focuses not only on knowledge transfer, but on the acquisition of general entrepreneurial skills, the ability to identify opportunities, the ability to make decisions and take a risk of own decision, stimulate the capacity for selforganization, develop communication and work team skills etc.

At the international level, the development of entrepreneurial education is carried out extensively on the basis of various projects aimed at stimulating young people's initiatives, which favors the context of bringing the business environment closer to the academic and professional environment.

In the Republic of Moldova, the entrepreneurial environment is a developing process aimed at attracting young people to increase it, and entrepreneurial education became an important element of the initial and continuing training of specialists in various fields. It is supported and promoted by the Education Development Strategy and the Education Code in RM, which clearly states that one of the key competencies is entrepreneurial competence and initiative. Over the last few years, various projects have been launched on the national level to support the development of entrepreneurial education, promoted by various organizations and centers.

The project "Collaborative Entrepreneurial Education", financed by the European Union through the Cross-border Program Romania - Republic of Moldova, implemented by the Organization for the Development of the Small and Medium Enterprises Sector in RM in partnership with the Technical University of Moldova, the County Board of Small and Medium Enterprises from lași and "Gheorghe Asachi" Technical University from lași, Romania has as main goal to increase the access to a qualitative training in the field of Entrepreneurship, the development of students' entrepreneurial skills, the formation of a new generation of entrepreneurs for the textile industry, which is a key industry of Moldova.

At the first stage of the project, a study was conducted to identify and assess the training needs in the field of entrepreneurship for students of the Faculty of Textiles and Polygraphy in the Technical University of Moldova and students of the Faculty of Industrial Design and Business Management in the "Gheorghe Asachi" Technical University from Iasi, Romania. The study aimed to identify training needs in entrepreneurship and formulate recommendations on entrepreneurial education of students, which will be included in the entrepreneurship course implemented in the project and possibly in the curriculum, in order to bring about conceptual and practical changes on the training of students' knowledge and skills, applied on the market.

The study highlighted an increased interest of students in entrepreneurial education. Most students are attracted to the idea of starting their own business and have demonstrated the need to gain more knowledge in the field of entrepreneurship to implement their own ideas. The level of knowledge and skills that students acquire in the university curriculum is not enough to stimulate entrepreneurship. Thus, in addition to the university study program, students need entrepreneurial training, based on specific and practical aspects, for professional development in the entrepreneurial field. Students also believe that teaching methods need to focus on practicality on modern teaching tools and interactive technologies. They are interested in case study of successful businesses, business simulation and business process modeling, working in a team and especially interacting with experienced entrepreneurs.

Acknowledgment. The research was conducted within the cross-border project “Collaborative Entrepreneurial Education" no. MS ENI Code 2SOFT/1.1/1. 
24 The importance and necessity of entrepreneurial education for students on the textile and polygraphy faculty...

\section{References}

1. Importanța educației antreprenoriale [Online]. Available at https://www.edusoft.ro/importanta-educatieiantreprenoriale/

2. Buciuceanu-Vrabie, Mariana; Gagauz, Olga, Tinerii pe piața muncii din Republica Moldova: competențe și aspirații [Online]. Available at http://dspace.ince.md/xmlui/handle/123456789/1134

3. Cheung, C. K., \& Chan, R. (2011). The introduction of entrepreneurship education to school leavers in a vocational institute. International Journal of Scientific Research in Education, 4, pp. 8 - 16.

4. Sergio Postigo M. Fernanda Tamborini, Entrepreneurship Education in Argentina: The Case of the San Andres University, 2004, In book: Business Education and Emerging MArket Economies, Perspectives and Best Practices, pp. 267 - 282.

5. Isaac Visser, Friedrick și Brijlal. Entrepreneurship education and training at the Further Education and Training (FET) level in South Africa, South African Journal of Education, Vol. 27 No. 4, 2007, pages.613-629.

6. Zoltan Acs, How Is Entrepreneurship Good for Economic Growth?, Innovations: Technology, Governance, Globalization, vol 1, issue 1, 2006, pp. 97 - 107.

7. Brannback \& Carsrud, Cognitive Maps in Entrepreneurship: Researching Sense Making and Action, 2009

8. Recomandarea 2006/962/CE privind competențele-cheie pentru învățarea pe tot parcursul vieții [Online]. Available at https://eur-lex.europa.eu/legal-content/RO/TXT/?uri=celex\%3A32006H0962

9. P7_TA(2013)0512 Planul de acțiune Antreprenoriat 2020: Relansarea spiritului de întreprindere în Europa [Online]. Available at https://www.europarl.europa.eu/doceo/document/TA-7-2013-0512_RO.pdf

10. EntreComp: The Entrepreneurship Competence Framework [Online]. Available at https://eufordigital.eu/wpcontent/uploads/2019/10/EntreComp_The-Entrepreneurship-Competence-Framework.pdf

11. EntreComp: Cadrul de competențe antreprenoriale. [Online]. Available at https://ancd.gov.md/ro/content/entrecomp-europe

12. Todd A. Finkle, Donald F. Kuratko Michael G. Goldsby, Examination of Entrepreneurship Centers in the United States: A National Survey, Journal of Small Business Management, March 2006, 44(2):184 - 206

13. Codul educației al Republicii Moldova [Online]. Available at http://lex.justice.md/index.php?action=view \&view=doc \&lang=1\&id=355156

14.Strategia de dezvoltare a educației pentru anii 2014-2020 „Educaţia-2020” [Online]. Available at https://ust.md/wp-content/uploads/2019/03/2.Strategia-de-dezvoltare-a-educatiei-2014-2020_2014.pdf

15. Conceptul Strategiei de dezvoltare a educației pentru anii 2021-2030 „Educația-2030” și al Programului de implementare [Online]. Available at https://mecc.gov.md/sites/default/files/concept_strategie_program_de_implementare_educatia_2030.pdf

16. Comerț exterior, Forța de muncă și câștig salarial, Statistica. md [Online]. Available at https://statistica.gov.md/pageview.php?l=ro\&idc=407 \&nod=1\&

17. Activitatea și poziția financiară a agenților economici după mărime și activități economice, 2015-2020. Statistica.md [Online]. Available at https://statbank.statistica.md/PxWeb/pxweb/ro/40\%20Statistica\%20economica/40\%20Statistica\%20econo mica_24\%20ANT_ANT030/ANT030060.px/?rxid=b2ff27d7-0b96-43c9-934b-42e1a2a9a774

18. Proiectul transfrontalier Collaborative Entrepreneurial Education [Online]. Available at https://www.odimm.md/ro/proiecte/cee

19. Raport privind rezultatele studiului de identificare a necesitaților de instruire în domeniul antreprenoriatului ale studenților facultății “Textile și Poligrafie” din cadrul Universității Tehnice a Moldovei, Chișinău, 2021

20. The 4 steps to SPIN Selling. [Online]. Available at https://www.lucidchart.com/blog/the-4-steps-to-spinselling 